\title{
A new glacier inventory for the European Alps from Landsat TM scenes of 2003: challenges and results
}

\author{
F. PAUL, H. FREY, R. LE BRIS \\ Department of Geography, University of Zürich-Irchel, Winterthurerstrasse 190, CH-8057 Zürich, Switzerland \\ E-mail: frank.paul@geo.uzh.ch
}

\begin{abstract}
Meltwater from glaciers in the European Alps plays an important role in hydropower production, and future glacier development is thus of economic interest. However, an up-to-date and alpine-wide inventory for accurate assessment of glacier changes or modelling of future glacier development has not hitherto been available. Here we present a new alpine-wide inventory (covering Austria, France, Italy and Switzerland) derived from ten Landsat Thematic Mapper (TM) scenes acquired within 7 weeks in 2003. Combined with the globally available digital elevation model from the Shuttle Radar Topography Mission, topographic inventory parameters were derived for each of the $\mathbf{3 7 7 0}$ mapped glaciers, covering $2050 \mathrm{~km}^{2}$. The area-class frequency distribution is very similar in all countries, and a mean northerly aspect (NW, N, NE) is clearly favoured (arithmetic counting). Mean glacier elevation is $\sim 2900 \mathrm{~m}$, with a small dependence on aspect. The total area loss since the previous glacier inventory (acquired around $1970 \pm 15$ years) is roughly one-third, yielding a current area loss rate of $\sim 2 \% \mathrm{a}^{-1}$. Digital overlay of the outlines from the latest Austrian glacier inventory revealed differences in the interpretation of glacier extents that prohibit change assessment. A comparison of TMderived outlines with manually digitized extents on a high-resolution IKONOS image returned $1.5 \%$ smaller glaciers with TM.
\end{abstract}

\section{INTRODUCTION}

Glacier decline in the European Alps has been particularly strong during recent decades, as observations and measurements of changes in length, area and mass revealed (e.g. Haeberli and others, 2007; Paul and others, 2007; WGMS, 2009). Due to the important role of meltwater from Alpine glaciers in hydropower production, repeated and accurate assessment of the glacier-covered area is a mandatory task for the related hydrological modelling (e.g. Koboltschnig and others, 2008; Viviroli and others, 2009). Of particular importance for change assessment or modelling of climate change impacts on glaciers is the availability of digital vector outlines for each glacier entity (e.g. Huss and others, 2008; Paul and Andreassen, 2009). Such vector datasets are currently compiled in the framework of the Global Land Ice Measurements from Space (GLIMS) initiative from satellite imagery for nearly all parts of the world (e.g. Kargel and others, 2005; Raup and others, 2007; Paul, 2010).

In the European Alps, a variety of sources (different satellites, aerial photography, laser scanning), methods (automated mapping, manual delineation) and acquisition periods (1997-2006) was recently applied to update national inventories and to calculate changes compared to a previous inventory (e.g. Paul and others, 2004b; Citterio and others, 2007; Lambrecht and Kuhn, 2007; Abermann and others, 2009). As these datasets lack the spatio-temporal consistency required for alpine-wide applications (e.g. in regional climate models; Kotlarski and others, 2010), we have created in the framework of the European Space Agency's (ESA) GlobGlacier project (Paul and others, 2009a) a new glacier inventory for the entire Alps from ten Landsat Thematic Mapper (TM) scenes acquired within a 2 month period in the late summer of 2003. This short acquisition period is of particular value for modelling and change assessment (e.g. Andreassen and others, 2008). For comparison, glacier data from the Alps which are available in the World Glacier Inventory (WGI) have been compiled over a 30 year period from data sources (topographic maps, aerial photography) mainly generated between 1955 and 1985 (Zemp and others, 2008). As the WGI only provides point information (coordinates) from each glacier, change assessment is difficult. We have thus also compared our outlines against the recently released glacier inventory from Austria which was compiled from aerial photography mainly acquired over the 1997-99 period and provides glacier outlines in vector format (Lambrecht and Kuhn, 2007).

For all kinds of modelling it is also of great value to have the complementary topographic information (e.g. minimum, maximum and median elevation) for each glacier in the database (e.g. Haeberli and Hoelzle, 1995; Braithwaite, 2009). This information can be derived for nearly all parts of the world from freely available digital elevation models (DEMs) such as the Shuttle Radar Topography Mission (SRTM) DEM with $\sim 90 \mathrm{~m}$ spatial resolution (Farr and others, 2007) or the Advanced Spaceborne Thermal Emission and Reflection Radiometer (ASTER) global DEM (GDEM) with $30 \mathrm{~m}$ cell size (Hayakawa and others, 2008). Whereas national DEMs might have a higher accuracy and/or better spatial resolution, they are often not freely available and might refer to much earlier dates. For the Alps, we found that data voids in the SRTM DEM are generally located outside of glaciers (Paul and Haeberli, 2008) and that the GDEM has partly strong artefacts over glaciers. Though this has little impact on most of the derived parameters (Frey and Paul, in press), we have decided to derive topographic attributes as well as drainage divides for each glacier from the SRTM DEM with $3^{\prime \prime}$ resolution. The entire inventory will be made freely available in the GLIMS glacier database (www.glims.org). 


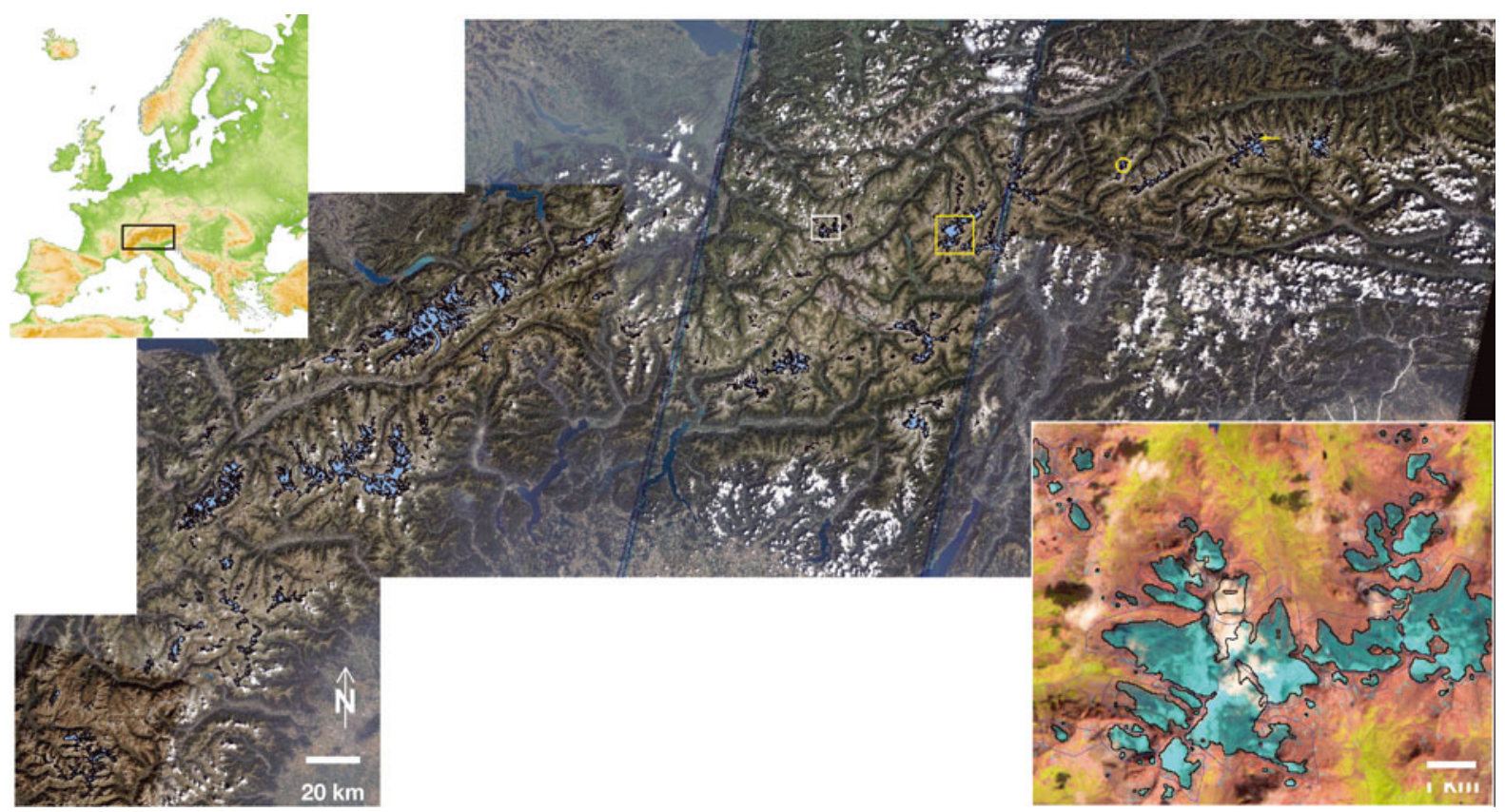

Fig. 1. The European Alps study region as seen in natural colours with a mosaic of the Landsat 5 TM scenes used for the glacier mapping. Blue areas with black outlines indicate individual glaciers. Some regions with mostly small glaciers are not covered (e.g. Monte Visco, Zugspitze and Dolomites). The upper left inset shows the location of the study site in Europe (black square). The lower right image is a TM band 5, 4, 3 composite of the Silvretta Group (white square in main image) with clouds (white) partly hiding some glaciers (cyan). The yellow square denotes the location of Figure 2, the yellow circle the location of Figure $6 \mathrm{a}$ and the arrow the location of Figure $6 \mathrm{~b}$.

\section{STUDY REGION AND DATASETS}

\subsection{Study region}

The study region covers the glaciers in the Alps that are located in Austria, France, Italy and Switzerland (Fig. 1). In all four countries a few small glaciers are excluded either due to adverse snow conditions or local clouds. These will be added to the inventory when more suitable scenes become available. According to the WGI, the Alps host about 5150 glaciers covering $2910 \mathrm{~km}^{2}$ with sizes between 0.02 and $87 \mathrm{~km}^{2}$ (WGMS, 1989). Most glaciers are small $\left(80 \%\right.$ are $\left.<1 \mathrm{~km}^{2}\right)$, while only a few $(0.6 \%)$ are $>10 \mathrm{~km}^{2}$ but these cover $22 \%$ of the total glacier area. The highest elevation is found at Mont Blanc (Monte Bianco; $4808 \mathrm{~m}$ a.s.I.), and mean glacier elevation is $\sim 2900 \pm 300 \mathrm{~m}$. With an assumed total glacier volume of about $100-130 \mathrm{~km}^{3}$ in the Alps in the 1970s (Haeberli and Hoelzle, 1995; Paul and others, 2004a), an average mean glacier thickness of about 35-45 m can be derived. Of course, this average is strongly influenced by a few very large glaciers, and most glaciers (by number) have mean thickness values of $25 \mathrm{~m}$ or less (Farinotti and others, 2009). Nearly all glaciers in the Alps are temperate, with the exception of glaciers in or originating at high altitudes $(>3500 \mathrm{~m})$ that can be partly cold (Suter and others, 2001). Regarding precipitation conditions, most glaciers are situated in a transitional climatic regime, but many also experience more wet/maritime (at the northern rim) or dry/continental (in the interior) conditions. An overview of the locally highly variable precipitation conditions in the Alps is provided by Schwarb (2000).

\subsection{Datasets}

In total we have analysed ten scenes from Landsat TM that were acquired between 30 July and 21 September 2003 (Table 1). All scenes were downloaded from the website glovis.usgs.gov where they were available at no cost after the opening of the US Geological Survey's Landsat archive (USGS, 2008). We delayed the processing until all scenes were available with L1T geometric correction, i.e. orthorectified with a DEM. Scenes of the same path were mosaicked before the processing. In the Alps, the summer of 2003 witnessed exceptional cloud and snow conditions as two intense heatwaves occurred at the end of June and in the second week of August (e.g. Schär and others, 2004). Combined with the high temperatures in July, these caused all snow outside of glaciers and partly also on the glaciers to melt away, so we had near-perfect glacier mapping conditions in most regions during August. This is of particular value for product quality, as shadow regions are

Table 1. Overview of the ten used Landsat 5 TM scenes from 2003

\begin{tabular}{lcccccccccc}
\hline & \multicolumn{10}{c}{ Scene No. } \\
& 1 & 2 & 3 & 4 & 5 & 6 & 7 & 8 & 9 & 10 \\
\hline Path & 191 & 192 & 193 & 193 & 194 & 194 & 195 & 195 & 195 & 196 \\
Row & 27 & 27 & 27 & 28 & 27 & 28 & 27 & 28 & 29 & 29 \\
Date & 17 Aug & 24 Aug & 30 Jul & 30 Jul & 6 Aug & 6 Aug & 13 Aug & 13 Aug & 13 Aug \\
\hline
\end{tabular}




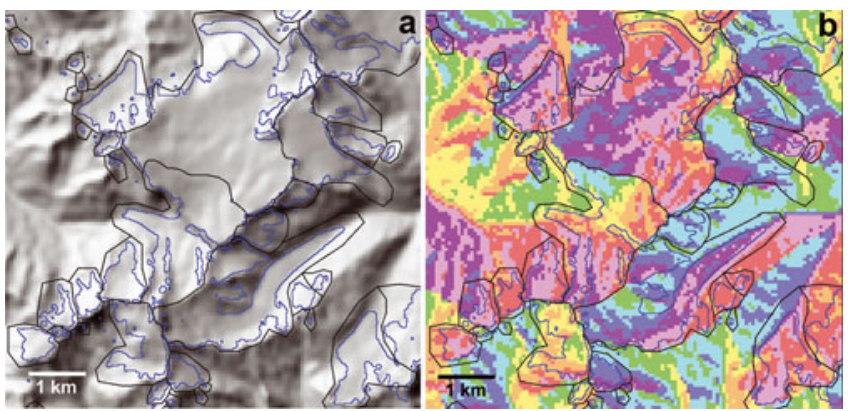

Fig. 2. (a) Hillshade of the SRTM 3 DEM resampled to $60 \mathrm{~m}$ spatial resolution with glacier outlines in blue and drainage basins in black. (b) Colour-coded flow-direction grid with glacier outlines and drainage divides as in (a). Each colour represents one cardinal direction from north (pink), to east (blue), south (green) and west (orange).

smaller than on the normally used late-September images due to the still high solar elevation in August. A snowfall event in early September caused poor snow conditions for the rest of the year, at least in most parts of the Alps. On some images a few glaciers were cloud-covered and we were fortunate to find suitable scenes ( 1 and 10 in Table 1) from neighbouring paths without clouds. However, for about ten glaciers in the Silvretta group (inset in Fig. 1) and Dauphiné we had to use additional scenes from 2009 to delineate their accumulation region.

Several smaller glaciers in various regions of Italy (e.g. Brenta group and Dolomites) are not yet included. To identify glacier entities and to make an overall calculation of area change we used the data from the WGI (WGMS, 1989).

To derive topographic glacier inventory parameters and drainage divides, a consistent DEM for the entire Alps is needed (e.g. Paul and others, 2009b). Several empirical tests and direct comparisons of the SRTM DEM, the ASTER GDEM and the DEM25 from swisstopo for glaciers in the Swiss Alps (Frey and Paul, in press) resulted in the decision to use the SRTM DEM (the void-filled version) for this purpose. The main reasons are: its acquisition date (February 2000) was still quite close to the year of the satellite scenes and clearly defined; it has fewer artefacts over glaciers and more distinct ridges at correct elevations than the GDEM; and for the entire region the quality is more consistent. We downloaded the respective tiles from the Consultative Group for International Agriculture Research (CGIAR; http://srtm.csi.cgiar.org/) and re-projected the mosaic to Universal Transverse Mercator (UTM) zone 32 (World Geodetic System 1984 (WGS84) datum) with $60 \mathrm{~m}$ cell size (as a compromise between the $30 \mathrm{~m}$ pixel size of the TM scenes and the $90 \mathrm{~m}$ resolution of the SRTM DEM). At this resolution, the smoothing of the ridges is still acceptable and topographic inventory parameters remain nearly unchanged (Frey and Paul, in press).

A hillshade of this DEM is shown for a subregion of the study site in Figure 2a to visualize its level of detail.

The vector outlines for the glaciers of the Austrian Alps were recently made available on the University of Innsbruck website (http://imgi.uibk.ac.at/iceclim/glacierinventory). This dataset was manually digitized from high-resolution aerial photography mainly acquired between 1997 and 1999 (Lambrecht and Kuhn, 2007). We downloaded this dataset and re-projected it to UTM zone 33 (with WGS84 datum) for overlay and comparison.

\section{METHODS}

\subsection{Glacier mapping}

All glaciers are classified in the main processing stage with a thresholded ratio image (TM3/TM5) and an additional threshold in TM1 to improve the classification in shadow regions (e.g. Paul and Kääb, 2005). By dividing the high reflectance values of ice and snow in the visible band (TM3) by the very low reflectance values in the shortwave infrared (TM5), a strongly contrast-enhanced ratio image resulted that is used to separate snow and ice (i.e. glaciers) from other terrain with a threshold. Several studies proved that this simple method is also very robust (regarding the threshold selection) and accurate compared to other methods (e.g. Paul and others, 2003; Andreassen and others, 2008). Of course, glacier ice under optically thick debris cover is not mapped by this method, and misclassification of turbid lakes also occurs. Although semi-automated techniques to determine the debris-covered glacier parts have been developed (e.g. Bishop and others, 2001; Paul and others, 2004a), we have edited all outlines in the post-processing stage by manual digitization using contrast-enhanced false-colour composites of the respective satellite scenes in the background. In part, oblique perspective views in Google Earth $^{\mathrm{TM}}$ were used to facilitate the interpretation. Glacier outlines from all scenes were corrected in their original reference system (e.g. UTM33 for numbers 1 and 2 in Table 1) and only the final outlines were re-projected to UTM32 and mosaicked afterwards.

\subsection{Calculation of glacier inventory data}

As mentioned before, the DEM provides both drainage divides and topographic data for each glacier. For both purposes three additional raster datasets (grids) were derived from the DEM: flow-direction, slope and aspect grids. From the latter, sine and cosine grids were also calculated in order to determine a correct mean value for the circular variable aspect (e.g. Evans, 2006). The flow-direction grid was used to aid in digitizing a separate vector layer with the drainage divides of each glacier. In Figure $2 \mathrm{~b}$ a colour-coded version of this flow-direction grid is shown for a subregion of the study site along with the glacier outlines and the drainage divides. For the Swiss Alps we used the basin vector layer that was already prepared for the Swiss glacier inventory 2000 (cf. Paul, 2007); for the glaciers in Austria, France and Italy we used the codes from the WGI (converted to a point vector file) to identify individual glaciers according to the previous inventory. This overlay revealed that several, mostly small, glaciers are not covered by our inventory, as they were either cloud-covered or have disappeared. Due to inconsistencies in the former coding of glacier entities (e.g. when different drainage divides were used), we have not tried to perform a glacier-by-glacier comparison with the WGI data.

The basin vector layer is then digitally intersected with the corrected outlines to obtain individual glacier polygons, and a country code is assigned to each glacier by digital intersection with the polygons for each country. These were manually adjusted in regions with glaciers to avoid spatial overlap. The topographic inventory data per glacier were calculated from zone statistics following the method described by Paul and others (2002) and the guidelines by Paul and others (2009b) for each of the following parameters: minimum, maximum, mean and median elevation, mean slope and mean aspect. Glacier area and code is auto- 
Table 2. Count and area covered per size class for the entire dataset

\begin{tabular}{lrrrr}
\hline Size class & \multicolumn{2}{c}{ Count } & \multicolumn{2}{c}{ Area } \\
& $\mathrm{km}^{2}$ & $\%$ & $\mathrm{~km}^{2}$ & \multicolumn{1}{c}{$\%$} \\
& & & & \\
\hline $0.01-0.05$ & 1542 & 40.9 & 37.3 & 1.8 \\
$0.05-0.1$ & 520 & 13.8 & 37.1 & 1.8 \\
$0.1-0.5$ & 1031 & 27.4 & 239.9 & 11.7 \\
$0.5-1.0$ & 272 & 7.2 & 185.7 & 9.1 \\
$1-5$ & 326 & 8.6 & 665.9 & 32.5 \\
$5-10$ & 51 & 1.4 & 355.2 & 17.3 \\
$>10$ & 27 & 0.7 & 528.8 & 25.8 \\
Total & 3769 & 100 & 2049.9 & 100 \\
& & & & \\
\hline
\end{tabular}

matically provided by the GIS; length is not yet included but will be added later.

\subsection{Accuracy assessment}

We performed two types of accuracy assessment: (1) overlay with glacier outlines that were independently digitized for the new Austrian glacier inventory from aerial photography, and (2) by comparison with glacier extents as digitized from a high-resolution IKONOS image acquired 2 weeks after the satellite scene. For (1) we compared our outlines only qualitatively, as the snow conditions were too different for a quantitative assessment. However, we find this overlay very helpful as it provides insight into the quality of the automatically derived outlines and the interpretation of debris-covered glacier parts. For (2) we used screen shots from Google maps that were geocoded iteratively (assuming UTM projection, zone 32 and WGS84 datum) until a good match with the Landsat scene was achieved for the respective subset. The extent of three differently sized glaciers on the IKONOS image was digitized once and on the Landsat image five times (each by another analyst) to assess differences in interpretation. The mean value of the multiple digitizations and the area from the IKONOS scene is then compared to the automatically derived area.

\section{RESULTS}

\subsection{Inventory parameters}

The count and area per size class for all 3770 glaciers in the sample are depicted in Figure 3a in bar graph form using the relative values. Table 2 also lists the absolute numbers for all size classes. Though the size classes have somewhat arbitrary boundaries, they reflect well the general characteristic of most glacierized mountain ranges, with abundant small glaciers present in regions with a few larger ones. For this overall inventory we computed a total area of $2050 \mathrm{~km}^{2}$, with $82 \%$ of all glaciers smaller than $0.5 \mathrm{~km}^{2}$ (covering $15 \%$ of the total area) and $11 \%$ larger than $1 \mathrm{~km}^{2}$ covering $75 \%$ of the area. The high number of glaciers (1030) in the $0.1-0.5 \mathrm{~km}^{2}$ class $(27 \%)$ contribute a substantial amount $(>11 \%)$ to the total area. Neglecting this fraction and the even smaller entities would thus result in an incomplete inventory. When analysing the size class distribution per country, the fractions are roughly similar, with the largest glaciers found in Switzerland and a comparably higher proportion of them in the Swiss sample. Compared to the area reported in the WGI $\left(2909 \mathrm{~km}^{2}\right)$, the area loss is $\sim 30 \%$. As most of the loss took
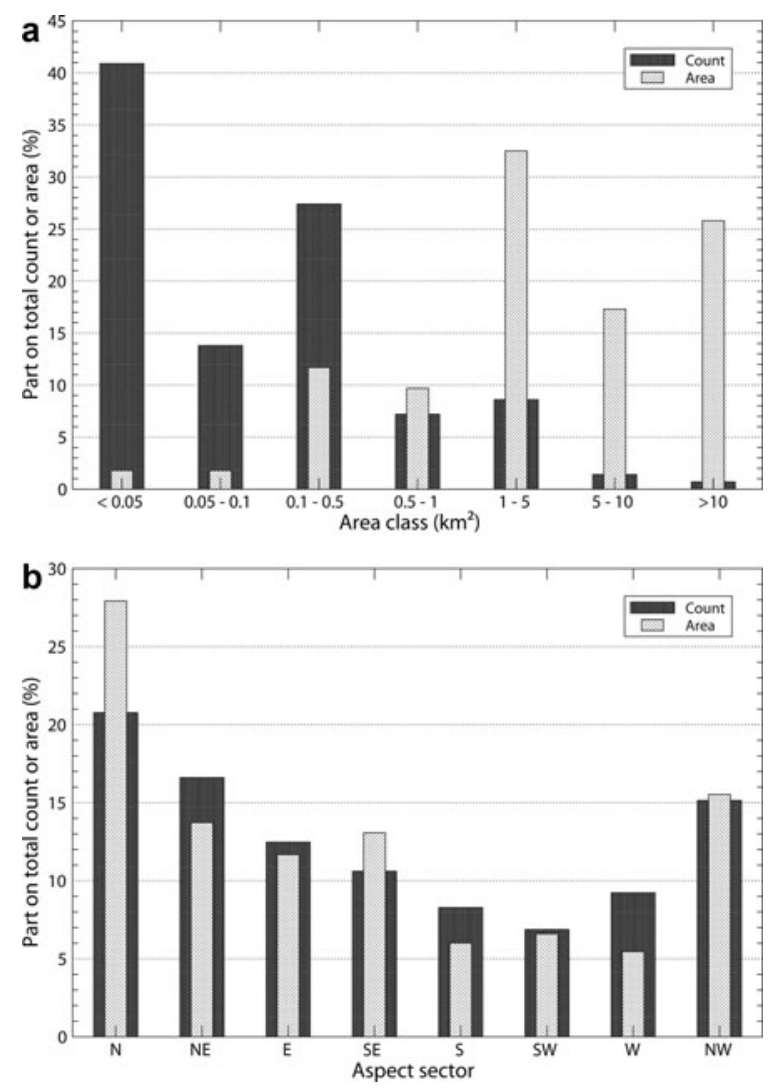

Fig. 3. (a) Histogram of the count and area distribution per size class for the entire sample. (b) Same as (a) but for each aspect sector.

place after 1985 (Paul and others, 2004b), a mean area loss of $2 \% \mathrm{a}^{-1}$ results over this time period.

When analysing the number and area of glaciers per aspect sector (Fig. 3b), we found that $52.5 \%$ of all glaciers face to the northern quadrant (northwest, north, northeast) whereas only $25.8 \%$ face to the southern quadrant (southeast, south, southwest). The area covered by the glaciers facing in these directions is rather similar $(57.2 \%$ and $25.7 \%$ respectively). A slightly higher proportion of glaciers face east than face west. The comparatively large area covered by glaciers with southeast aspect is due to the mean aspect of the largest glacier in the sample (Grosser Aletsch). The count of aspect sectors for individual DEM cells gives more similar amounts for all sectors. This is because most of the cells from several of the largest glaciers (e.g. Grosser Aletsch, Fiescher, Miage, Rhone, Pasterze) are directed south rather than north. At the DEM cell scale, the asymmetry of glacier aspects (Evans, 2006) is thus less pronounced.

The variability of mean elevation with glacier aspect is depicted for all individual glaciers in the scatter plot of Figure $4 \mathrm{a}$ along with mean values per aspect sector. Apart from the already mentioned higher number of glaciers facing north, a tendency for lower mean elevations of north-facing glaciers can be seen. In the mean over the eight aspect sectors, glaciers facing south or southwest have $200 \mathrm{~m}$ higher mean elevations than north-facing glaciers. There is, however, also a correlation of mean elevation with precipitation amounts, and the regions along the northern Alpine rim receive more precipitation and have predominantly north-facing glaciers. This autocorrelation must be considered when interpreting the lower mean elevations in climatic terms. 

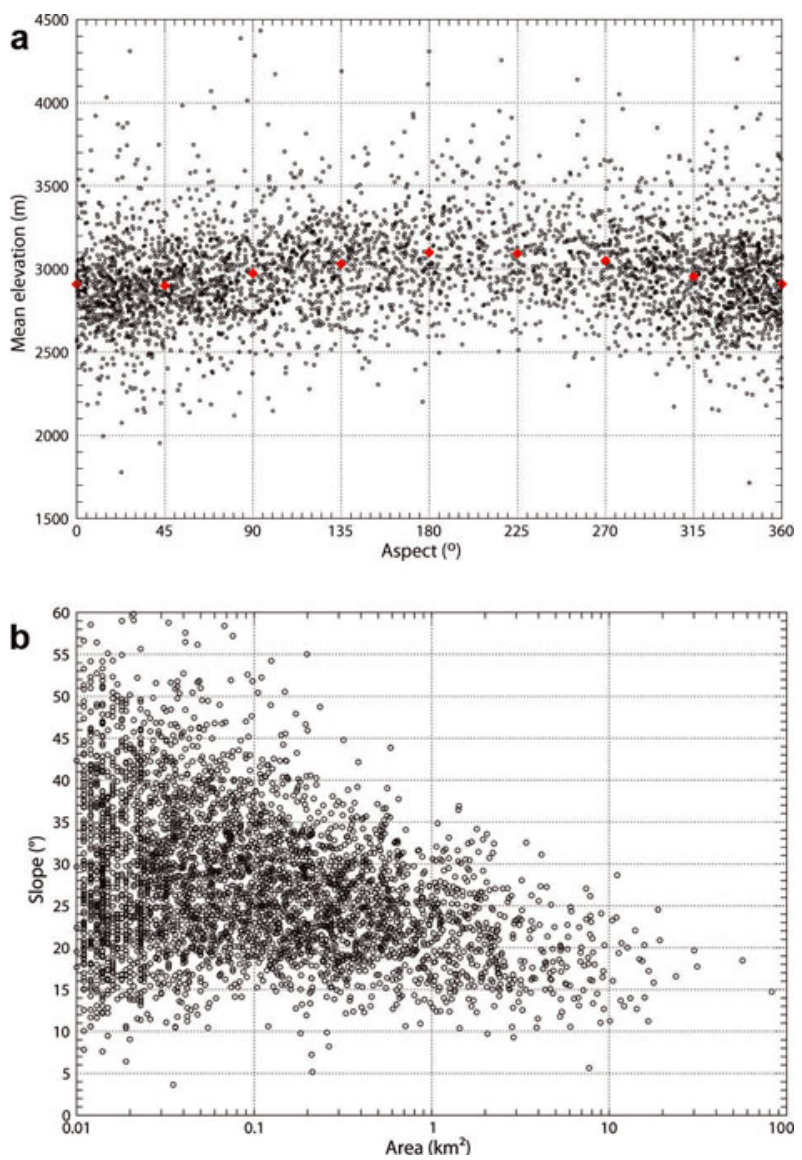

Fig. 4. (a) Mean glacier elevation vs aspect for all individual glaciers and mean value per aspect sector (red dots). (b) Mean glacier slope vs glacier area for the entire sample.

A scatter plot showing mean slope (derived from the DEM cells) vs glacier size is shown in Figure $4 \mathrm{~b}$. The tendency of larger (valley) glaciers to have lower mean slopes and of smaller (mountain) glaciers to be steeper is well known. The more interesting point is the increasing scatter of values towards smaller glaciers. This implies that smaller glaciers in a mountain range such as the European Alps can have nearly any slope and can thus be situated in all kinds of terrain. The reaction of these small glaciers to climate change is thus highly variable (e.g. due to the increase of topographic shading in steep valley walls) and the smallest glaciers do not necessarily have to disappear once temperatures increase. The large scatter of mean slope values for glaciers of the same size (e.g. $5-30^{\circ}$ for $10 \mathrm{~km}^{2}$ size) also hints at a high variability of mean thickness values and the importance of considering slope in the related calculations (e.g. Haeberli and Hoelzle, 1995).

When plotting minimum and maximum elevation vs glacier size (Fig. 5a), we found clearly different values only for glaciers larger than $1 \mathrm{~km}^{2}$. Glaciers smaller than this but larger than $0.1 \mathrm{~km}^{2}$ show some overlap and are restricted to the elevation range $2000-4000$ ma.s.l. Glaciers smaller than $0.1 \mathrm{~km}^{2}$ occur in nearly all elevation bands, which confirms that their reaction to climate change is difficult to generalize. There is no dependence of mean elevation on glacier size. The hypsographic curves (area distribution with elevation) summarized for each of the four countries are illustrated in Figure 5b. Apart from the different magnitudes of glacierization in each country, all four have most of the
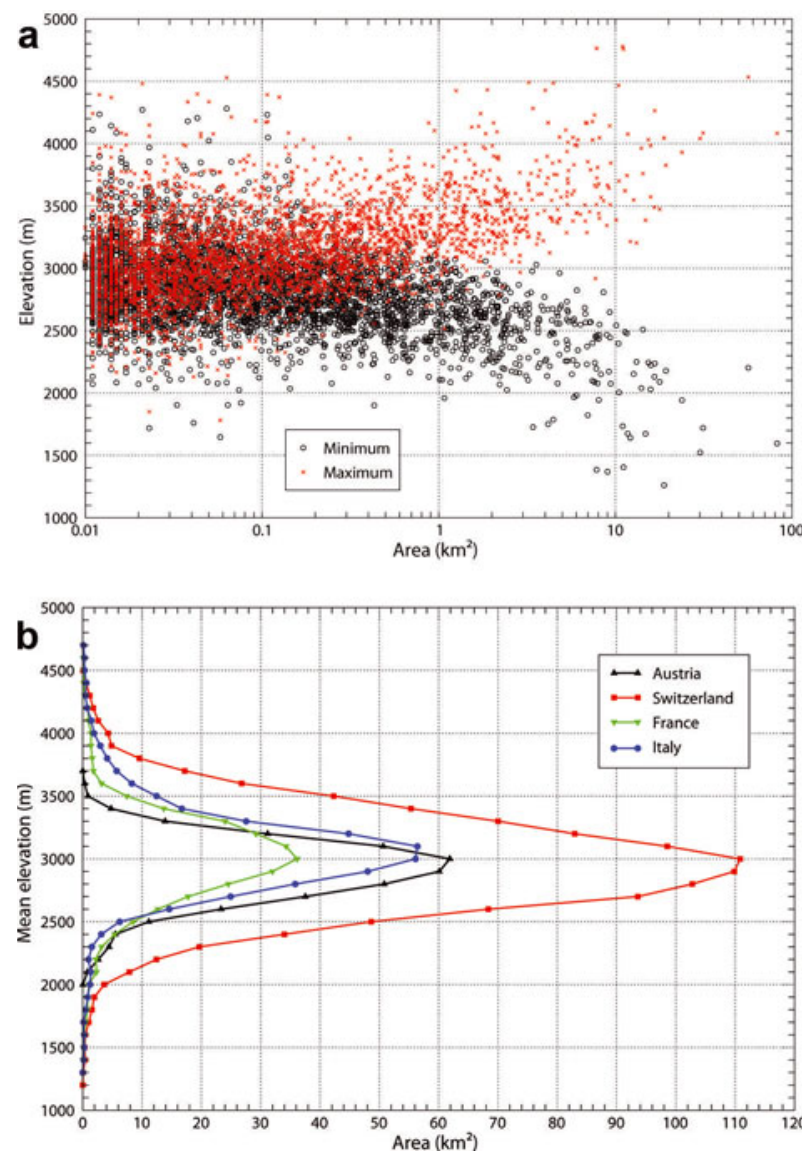

Fig. 5. (a) Minimum (black) and maximum (red) elevation vs glacier size for the entire sample. (b) Area-elevation distribution summarized for each of the four countries (see legend).

ice in the $3000 \mathrm{~m}$ elevation band $( \pm 100 \mathrm{~m})$ which is in good agreement with the mean overall elevation (Fig. 4a). The smallest elevation range is found for glaciers in Austria, where the highest mountain (Grossglockner) does not exceed $3800 \mathrm{~m}$, whereas some glaciers in Italy and France originate at the highest mountain in the Alps, Mont Blanc with $4808 \mathrm{~m}$ elevation. Comparing the approximately similar hypsographies for Austria and Italy, a generally $100-200 \mathrm{~m}$ shift of the distribution to lower elevations is visible for glaciers in Austria.

\subsection{Accuracy}

The overlay of glacier outlines from the recent Austrian inventory and 2003 (this study) reveals several interesting issues (Fig. 6). At first glance, there is an overall good agreement of the outlines (particularly in the unchanged accumulation region of the larger glaciers). However, on closer inspection differences appear:

1. There is a slight shift of the 1998 outlines compared to the satellite scene. This indicates that the projection routine in the GIS software used has problems with the projection of the Austrian coordinate system

2. Strong area losses can be seen in both images, particularly for smaller glaciers of which several have even disappeared. This confirms the previously found continuation of the strong glacier area loss in the Alps since 1998 (e.g. Paul and others, 2007). 

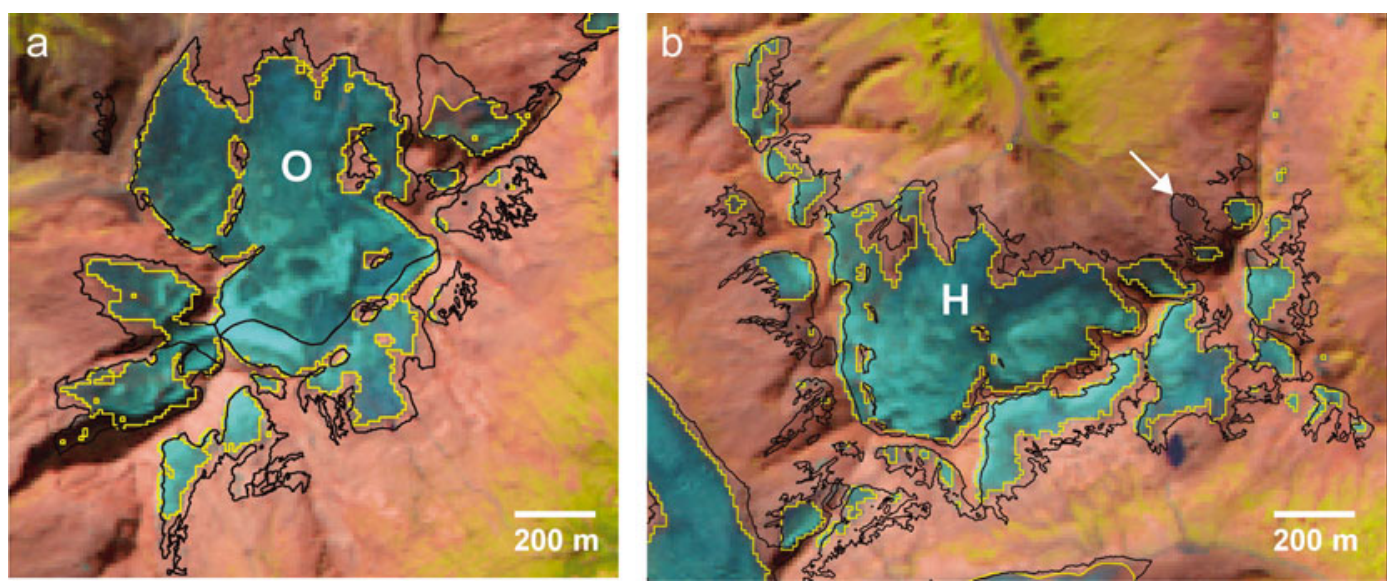

Fig. 6. Examples from glacier outlines as mapped here for 2003 (yellow lines) and for the Austrian glacier inventory for the $\sim 1997-99$ period (black lines). The background shows false-colour composites with bands 5, 4, 3 (as red, green, blue) of the TM scene used ( 1 pixel = $30 \mathrm{~m}$ ). (a) Olperer Ferner $(\mathrm{O})$ in the Zillertal Alps; (b) Habachkees $(\mathrm{H})$ in the Hohe Tauern range. The arrow points to a debris-covered glacier that was not properly corrected in the 2003 inventory.

3. The shape of the outlines from the Austrian inventory is often much more irregular and has locally extended parts. This indicates that perennial and perhaps also some seasonal snowfields were included in the glacier area. The obviously strong area loss seen at some glaciers might also be caused by disappearance of snow rather than glacier ice.

4. For some debris-covered, dirty or shadowed glaciers, the 2003 outlines have underestimated the 'real' glacier extent. This indicates that a more careful interpretation during manual editing is required when working at the pixel level and that outlines from a former inventory are very helpful for glacier identification, even when snow conditions were less good and glacier extents have changed in the meantime.

Our major conclusion from this comparison is that it is not advisable to directly calculate glacier area changes from the two datasets as they were obviously derived differently.
Apart from the required correction of the 2003 outlines in some places, the differences in interpretation of the glacier outlines dominate the visible change.

The outlines from the multiple digitizations for the quantitative accuracy assessment are depicted in Figure 7 with the IKONOS image in the background. The overlay reveals that the TM-derived outlines are generally within the variability of the manual digitizations, i.e. the automated classification with TM provides a suitable mean value. The good agreement is confirmed when comparing the TMderived areas for the three glaciers to the mean value of the respective manual digitizations (Table 3 ): The differences are $<0.01 \mathrm{~km}^{2}$ for all three glaciers. The relative differences are within $\pm 1 \%$ for three comparisons and between $4 \%$ and $-11 \%$ for the other three. The $-11 \%$ difference from the manual digitizations is likely related to difficulties in accurately digitizing this glacier manually, as the standard deviation of the area differences is $12 \%$. Overall, the glacier is $\sim 4 \%$ larger with TM than from the digitization on the high-resolution image.
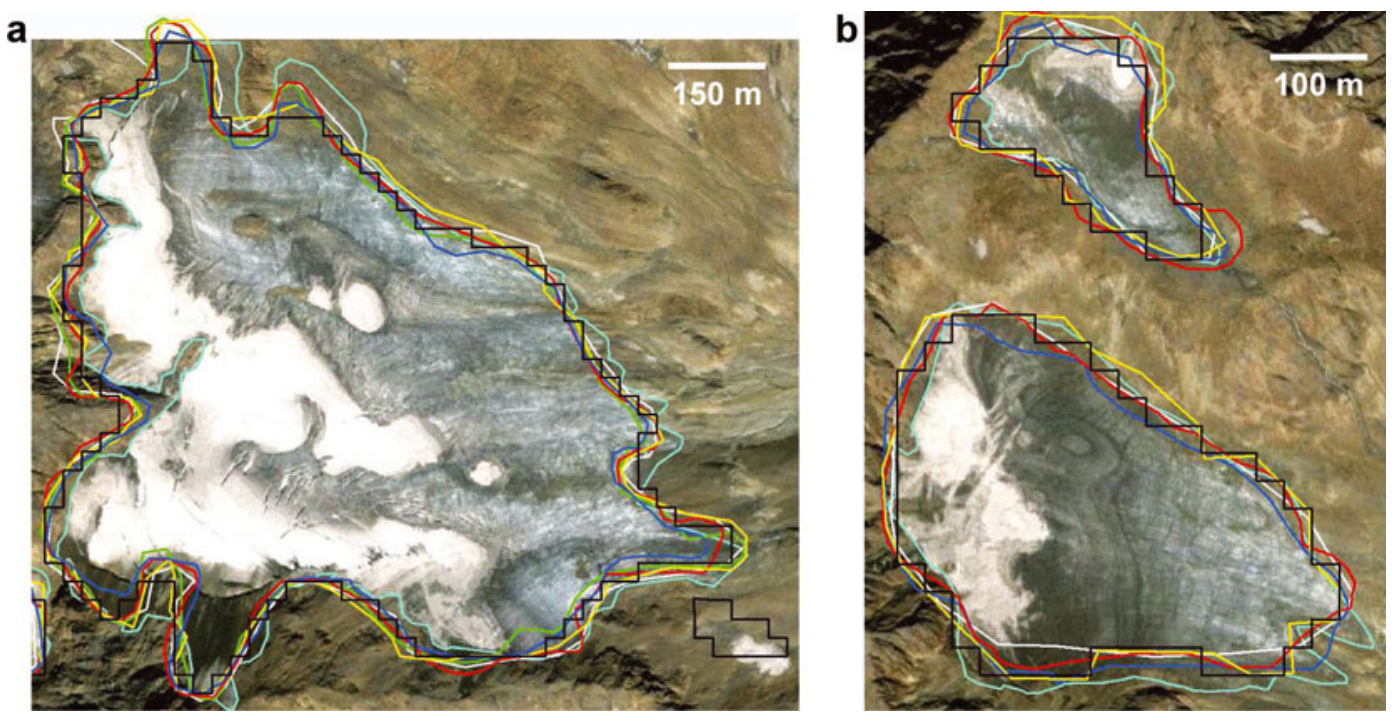

Fig. 7. Overlay of the automatic classification with Landsat TM (black), a manual digitization using the high-resolution IKONOS scene (cyan) in the background (screenshot from Google maps), and the multiple manual digitizations of the outline based on the TM scene (all other colours). Both glaciers are located in South Tyrol, Italy, close to Hintereisferner: (a) Steinschlagferner, (b) Schwemser Ferner. 
Table 3. Glacier areas as derived automatically from TM and by manual digitization on the TM and IKONOS image along with the relative differences from the size derived by TM. The standard deviation for the multiple digitizations is also given (Std dev.). The bottom row provides sums and differences for all three glaciers

\begin{tabular}{|c|c|c|c|c|c|c|}
\hline \multirow[t]{2}{*}{ No. } & \multirow{2}{*}{$\begin{array}{l}\mathrm{TM} \\
\mathrm{km}^{2}\end{array}$} & \multirow{2}{*}{$\begin{array}{c}\text { Manual on TM } \\
\mathrm{km}^{2}\end{array}$} & \multirow{2}{*}{$\begin{array}{c}\text { Difference from TM } \\
\%\end{array}$} & \multirow{2}{*}{$\begin{array}{c}\text { Std dev. } \\
\%\end{array}$} & \multicolumn{2}{|c|}{ Manual on IKONOS Difference from TM } \\
\hline & & & & & $\mathrm{km}^{2}$ & $\%$ \\
\hline 1 & 0.656 & 0.659 & -0.40 & 4.5 & 0.661 & -0.74 \\
\hline 2 & 0.129 & 0.128 & 0.25 & 3.6 & 0.137 & -6.37 \\
\hline 3 & 0.033 & 0.037 & -10.48 & 12.3 & 0.032 & 4.27 \\
\hline All & 0.820 & 0.824 & -0.71 & & 0.830 & -1.48 \\
\hline
\end{tabular}

\section{DISCUSSION}

\subsection{Glacier mapping}

Finding the correct threshold for glacier classification and removing gross errors (lakes, rivers) is comparably fast for an individual scene $(<1$ hour). However, it has to be mentioned that work on the 2003 inventory benefited greatly from ideal mapping conditions (there was generally no seasonal snow outside of glaciers) in the extremely hot and dry summer of 2003 which was devastating for most glaciers. For $\sim 30$ glaciers in several regions (e.g. Vanoise, Glarner Alps, Silvretta and Ankogel group) clouds hid part of the glacier perimeter and this was corrected by integrating additional Landsat scenes (mostly from September 2009). As these corrections were mainly required in the accumulation region, we consider the area changes due to the scene acquisition 6 years later to be small.

The new glacier inventory for the entire Alps presented here has the clear advantage of being compiled within a comparably short period of time (7 weeks) compared to the previous inventory available from the WGI (WGMS, 1989). However, due to the reduced spatial resolution of the satellite data used $(30 \mathrm{~m})$ compared to the WGI that was derived from aerial photography, the satellite product might be considered less accurate, particularly for small and/or debris-covered glaciers. On the other hand, the false-colour composites with TM bands 5, 4 and 3 (as red, green, blue) often show the (clean) ice extent more clearly than panchromatic images and are much easier to interpret in this regard. New techniques like the determination of glacier extents from (repeat) airborne laser scanning (Abermann and others, 2010) are promising, but still very expensive when applied over large regions.

Compared to the compilation of the previous alpine-wide glacier inventory from the mid-1970s, the creation of an inventory from automated classification of satellite data with manual editing and DEM fusion is certainly much faster. However, the workload to accurately digitize debriscovered glacier parts is high (up to two-thirds of the total time), and the work must be done repeatedly, i.e. for each inventory. The effort required to digitize the drainage divides to separate contiguous ice masses is also high (maybe onethird of the required time), but they need to be digitized only once. This vector layer can then also be used for the next inventory, given that the orthorectification of the satellite imagery is sufficiently accurate (e.g. Svoboda and Paul, 2009). For glaciers in Switzerland we have only reprojected the basins used for the 1998/99 inventory (Paul, 2007) to UTM zone 32 and reapplied them to the glacier map.

\subsection{Accuracy considerations}

The comparison with the last inventory for the Austrian Alps revealed general differences in the interpretation of glacier extents, making a quantitative calculation of area changes impossible. Though the consideration of perennial snowfields was required to be consistent with the interpretation of the 1969 inventory, the area changes derived by Lambrecht and Kuhn (2007) are likely a lower bound as the included perennial snowfields do not change much over time (DeBeer and Sharp, 2009). If seasonal snow had also been included in some regions (as inferred from the shape of the outlines), the real area loss of the glaciers would be even higher.

In agreement with results from previous studies (e.g. Paul and Kääb, 2005; Andreassen and others, 2008), we found for the three glaciers analysed here in more detail a mean area difference of $-1.5 \%$ compared to manually derived outlines on a high-resolution IKONOS image. For individual and, in particular, small or debris-covered glaciers the differences are likely higher, but in the mean of a larger sample they are likely not, as the deviations are normally distributed (i.e. omission and commisson errors average out as Fig. 7 shows). As the glaciers we analysed here are largely debris-free, we conservatively conclude that the accuracy of the automatically derived glacier area with $\mathrm{TM}$ is better than $3 \%$ in the mean for a larger sample of glaciers and up to $5-10 \%$ for individual glaciers. On the other hand, the standard deviations of the area differences from the multiple digitizations are also in the order of $5-10 \%$, indicating that the automated mapping of clean ice is at least as precise as the manual digitization.

\subsection{Glacier change}

Although a direct comparison with the total area reported in the WGI has several shortcomings (e.g. different sample; reference date from the WGI spans a 30 year period), we consider the calculated area loss of $30 \%$ as a good approximation for the loss since the mid-1980s, as from the 1960s to 1980s most glaciers in the Alps showed little change in area or even advanced (Paul and others, 2004b). It has also to be considered that we have not yet included several small glaciers in each country (e.g. around Monte Visco, Zugspitze and the Dolomites). We assume that their total area is in the order of $20-30 \mathrm{~km}^{2}$. Furthermore, we likely have failed to map the debris-covered parts of some smaller glaciers correctly (see Fig. 6b). We assume that this gives an additional $10-20 \mathrm{~km}^{2}$ of glacier area that is not included. Thus our total area is a lower bound, and a more correct value would be in the range $2080-2100 \mathrm{~km}^{2}$. The total area reduction since the mid-1970s is thus $\sim 820 \mathrm{~km}^{2}$, 
or $\sim 40 \mathrm{~km}^{2}$ (or $2 \%$ ) $\mathrm{a}^{-1}$ when 1984 is used as the starting year for the area loss. This is likely one of the highest mean annual area loss rates worldwide over this period.

\subsection{Topographic parameters}

The topographic parameters for each glacier were calculated from the SRTM DEM which was resampled to $60 \mathrm{~m}$ cell size during re-projection from geographic coordinates to UTM zone 32. Though this largely retains the original values in steep topography, a glacier with a size of $0.01 \mathrm{~km}^{2}$ only covers about three DEM cells at this resolution. The derived elevation or slope/aspect values hence become somewhat arbitrary. Moreover, the quality of the SRTM DEM is variable, and the filled values that replace large data voids can be subject to considerable errors. We thus expect that for several glaciers the calculated topographic parameters are outside acceptable error bounds, particularly for glaciers smaller than $0.1 \mathrm{~km}^{2}$. For glaciers larger than this, the derived values are likely sufficiently accurate, as a direct comparison of parameters as derived from two other DEMs has shown (Frey and Paul, in press). For parameters like minimum elevation, the close temporal coincidence of the DEM with the satellite image can actually be more important for its accuracy than the accuracy of the DEM.

The general east-west orientation of the Alps results in several north-south-oriented local valleys, with most glaciers $(52 \%)$ having a mean orientation towards northern sectors. Thus, topography certainly plays a role or in some regions even constrains the dominant aspect of the glaciers. The $200 \mathrm{~m}$ lower mean elevation for north-facing glaciers can also partly be explained by the higher precipitation values at the northern alpine rim and is thus not only a result of reduced global radiation and increased topographic shading. However, the correct consideration of these effects is difficult and they might be investigated in a future study.

\section{CONCLUSIONS}

We have presented results from a new glacier inventory for the entire European Alps that was derived from ten Landsat TM scenes acquired within 7 weeks in 2003 (with some local corrections from further scenes). This new inventory is methodologically and temporally much more consistent than the previous data available from the WGI, which is of great benefit for several applications (e.g. change assessment, modelling). However, it should not be seen as a replacement for national inventories that have been or will be compiled by other teams. It is a special product for a special purpose and needs to be completed in several regions. Independent of this, the statistical analysis of the inventory data revealed that nearly $90 \%$ of all glaciers are smaller than $1 \mathrm{~km}^{2}$, with a contribution of $25 \%$ to the total area which is $\sim 2050 \mathrm{~km}^{2}$ plus the still missing glaciers and unmapped glacier parts. The area loss since the 1980s is $\sim 30 \%$, which gives a mean annual area loss of $\sim 40 \mathrm{~km}^{2}$ $(2 \%) \mathrm{a}^{-1}$. The mean elevation of all glaciers is $\sim 2900 \mathrm{~m}$ and depends weakly on aspect but not on glacier size. Differences in the histograms of the size-class and areaelevation distributions among the four countries are small and related to the topographic characteristics of the mountain ranges in each country.

Whereas the main processing stage for image classification is rather fast and well established, clearly the highest workload is required in the post-processing stage for the manual editing of debris-covered glacier tongues and the digitizing of drainage divides to separate connected glacier entities. On the other hand, the final calculation of topographic information for all glaciers is very fast (i.e. automated). The use of a $60 \mathrm{~m}$ DEM to derive them is at the resolution limit for the smallest glaciers $\left(0.01 \mathrm{~km}^{2}\right)$ in the sample, and should be repeated once higher-resolution DEMs become available. A comparison with the recently released outlines from the Austrian glacier inventory reveals strong differences in the interpretation of perennial snowfields that were not present in our sample. The additional accuracy assessment with high-resolution IKONOS data confirmed previous accuracy estimates and indicated that the automatically derived outlines are as precise as manually digitized ones.

\section{ACKNOWLEDGEMENTS}

This study was performed in the framework of the ESAfunded GlobGlacier project (21088/07/I- EC). We thank R. Ranzi, an anonymous reviewer and the editors for helpful comments. Participants in the Karthaus Summer School helped with the multiple digitizations of glaciers.

\section{REFERENCES}

Abermann, J., A. Lambrecht, A. Fischer and M. Kuhn. 2009. Quantifying changes and trends in the glacier area and volume in the Austrian Ötzal Alps (1969-1997-2006). Cryosphere, 3(2), 205-215.

Abermann J., A. Fischer, A. Lambrecht and T. Geist. 2010. On the potential of very high-resolution repeat DEMs in glacial and periglacial environments. Cryosphere, 4(1), 53-65.

Andreassen L.M., F. Paul, A. Kääb and J.E. Hausberg. 2008. Landsat-derived glacier inventory for Jotunheimen, Norway, and deduced glacier changes since the 1930s. Cryosphere, 2(2), 131-145.

Bishop M.P., R. Bonk, U. Kamp, Jr and J.F. Shroder, Jr. 2001. Terrain analysis and data modeling for alpine glacier mapping. Polar Geogr., 25(3), 182-201.

Braithwaite R.J. 2009. After six decades of monitoring glacier mass balance we still need data but it should be richer data. Ann. Glaciol., 50(50), 191-197.

Citterio, M. and 6 others. 2007. The fluctuations of Italian glaciers during the last century: a contribution to knowledge about Alpine glacier changes. Geogr. Ann., Ser. A, 89(3), 167-184.

DeBeer, C.M. and M.J. Sharp. 2009. Topographic influences on recent changes of very small glaciers in the Monashee Mountains, British Columbia, Canada. J. Glaciol., 55(192), 691-700. (10.3189/002214309789470851.)

Evans, I.S. 2006. Local aspect asymmetry of mountain glaciation: a global survey of consistency of favoured directions for glacier numbers and altitudes. Geomorphology, 73(1-2), 166-184.

Farinotti, D., M. Huss, A. Bauder and M. Funk. 2009. An estimate of the glacier ice volume in the Swiss Alps. Global Planet. Change, 68(3), 225-231.

Farr, T.G. and 17 others. 2007. The Shuttle Radar Topography Mission. Rev. Geophys., 45(2), RG2004. (10.1029/ 2005RG000183.)

Frey, H. and F. Paul. In press. On the suitability of the SRTM DEM and ASTER GDEM for the compilation of topographic parameters in glacier inventories. Int. J. Appl. Earth Obs. Geoinform. (10.1016/j.jag.2011.09.020.)

Haeberli, W. and M. Hoelzle. 1995. Application of inventory data for estimating characteristics of and regional climate-change effects on mountain glaciers: a pilot study with the European Alps. Ann. Glaciol., 21, 206-212. 
Haeberli, W., M. Hoelzle, F. Paul and M. Zemp. 2007. Integrated monitoring of mountain glaciers as key indicators of global climate change: the European Alps. Ann. Glaciol., 46, 150-160.

Hayakawa, Y.S., T. Oguchi and Z. Lin. 2008. Comparison of new and existing global digital elevation models: ASTER G-DEM and SRTM-3. Geophys. Res. Lett., 35(17), L17404. (10.1029/ 2008GL035036.)

Huss, M., D. Farinotti, A. Bauder and M. Funk. 2008. Modelling runoff from highly glacierized alpine drainage basins in a changing climate. Hydrol. Process., 22(19), 3888-3902.

Kargel, J.S. and 16 others. 2005. Multispectral imaging contributions to global land ice measurements from space. Remote Sens. Environ., 99(1-2), 187-219.

Koboltschnig, G.R., W. Schöner, M. Zappa, C. Kroisleitner and H. Holzmann. 2008. Runoff modelling of the glacierized Alpine Upper Salzach basin (Austria): multi-criteria result validation. Hydrol. Process., 22(19), 3950-3964.

Kotlarski, S., D. Jacob, R. Podzun and F. Paul. 2010. Representing glaciers in a regional climate model. Climate Dyn., 34(1), $27-46$.

Lambrecht, A. and M. Kuhn. 2007. Glacier changes in the Austrian Alps during the last three decades, derived from the new Austrian glacier inventory. Ann. Glaciol., 46, 177-184.

Paul, F. 2007. The new Swiss glacier inventory 2000 - application of remote sensing and GIS. Schr. Phys. Geogr., Univ. Zürich 52.

Paul, F. 2010. Towards a global glacier inventory from satellite data: recent efforts and challenges to complete the global glacier inventory with modern geoinformatic techniques. Geogr. Helv., 65(2), 103-112.

Paul, F. and L.M. Andreassen. 2009. A new glacier inventory for the Svartisen region, Norway, from Landsat ETM+ data: challenges and change assessment. J. Glaciol., 55(192), 607-618.

Paul, F. and W. Haeberli. 2008. Spatial variability of glacier elevation changes in the Swiss Alps obtained from two digital elevation models. Geophys. Res. Lett., 35(21), L21502. (10.1029/2008GL034718.)

Paul, F. and A. Kääb. 2005. Perspectives on the production of a glacier inventory from multispectral satellite data in Arctic Canada: Cumberland Peninsula, Baffin Island. Ann. Glaciol., 42, 59-66.

Paul, F., A. Kääb, M. Maisch, T.W. Kellenberger and W. Haeberli. 2002. The new remote-sensing derived Swiss glacer inventory: I. Methods. Ann. Glaciol., 34, 355-361.

Paul, F., C. Huggel, A. Kääb, T. Kellenberger and M. Maisch. 2003. Comparison of TM-derived glacier areas with higher resolution data sets. EARSeL eProc., 2(1), 15-21.

Paul F., C. Huggel and A. Kääb. 2004a. Combining satellite multispectral image data and a digital elevation model for mapping debris-covered glaciers. Remote Sens. Environ., 89(4), 510-518.
Paul, F., A. Kääb, M. Maisch, T. Kellenberger and W. Haeberli. 2004b. Rapid disintegration of Alpine glaciers observed with satellite data. Geophys. Res. Lett., 31(21), L21402. (10.1029/ 2004GL020816.)

Paul, F., A. Kääb and W. Haeberli. 2007. Recent glacier changes in the Alps observed from satellite: consequences for future monitoring strategies. Global Planet. Change, 56(1-2), 111-122.

Paul, F., A. Kääb, H. Rott, A. Shepherd, T. Strozzi and E. Volden. 2009a. GlobGlacier: a new ESA project to map the world's glaciers and ice caps from space. EARSeL eProc., 8(1), 11.

Paul F. and 9 others. 2009b. Recommendations for the compilation of glacier inventory data from digital sources. Ann. Glaciol., 50(53), 119-126.

Raup B. and 11 others. 2007. Remote sensing and GIS technology in the Global Land Ice Measurements from Space (GLIMS) Project. Comput. Geosci., 33(1), 104-125.

Schär, C. and 6 others. 2004. The role of increasing temperature variability in European summer heatwaves. Nature, 6972(427), 332-336

Schwarb, M. 2000. The Alpine precipitation climate: evaluation of a high-resolution analysis scheme using comprehensive raingauge data. (PhD thesis, ETH Zürich.)

Suter, S., M. Laternser, W. Haeberli, R. Frauenfelder and M. Hoelzle. 2001. Cold firn and ice of high-altitude glaciers in the Alps: measurements and distribution modelling. J. Glaciol., 47(156), 85-96.

Svoboda F and Paul F. 2009. A new glacier inventory on southern Baffin Island, Canada, from ASTER data: I. Applied methods, challenges and solutions. Ann. Glaciol., 50(53), 11-21.

United States Geological Survey (USGS). 2008. Opening the Landsat archive. USGS Factsheet 2008-3091.

Viviroli, D., M. Zappa, J. Gurtz and R. Weingartner. 2009. An introduction to the hydrological modelling system PREVAH and its pre- and post-processing tools. Environ. Model. Softw. 24(10), 1209-1222.

World Glacier Monitoring Service (WGMS). 1989. World glacier inventory: status 1988, ed. Haeberli, W., H. Bösch, K. Scherler, G. Østrem and C.C. Wallén. IAHS(ICSI)-UNEP-UNESCO, World Glacier Monitoring Service, Zürich.

WGMS. 2009. Glacier Mass Balance Bulletin No. 10 (2006-2007) eds. Haeberli, W., I. Gärtner-Roer, M. Hoelzle, F. Paul and M. Zemp. ICSU(WDS)/IUGG(IACS)/UNEP/UNESCO/WMO, World Glacier Monitoring Service, Zürich.

Zemp, M., F. Paul, M. Hoelzle and W. Haeberli. 2008. Glacier fluctuations in the European Alps, 1850-2000: an overview and a spatiotemporal analysis of available data. In Orlove, B., E. Wiegandt and B.H. Luckman, eds. Darkening peaks: glacier retreat, science, and society. Berkeley, CA, University of California Press, 152-167. 